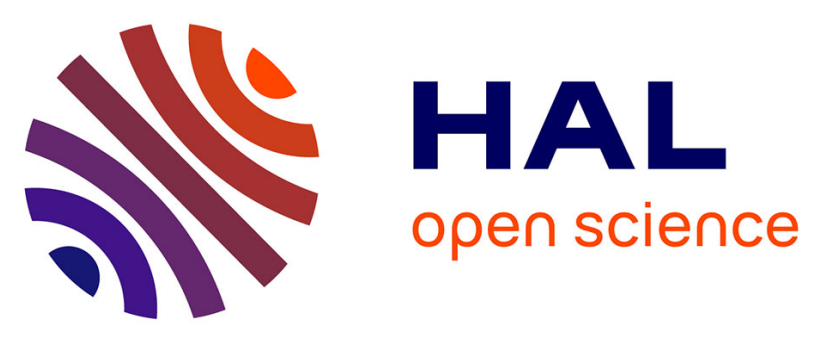

\title{
Impact of Agroecological Infrastructures on the Dynamics of Dysaphis plantaginea (Hemiptera: Aphididae) and Its Natural Enemies in Apple Orchards in Northwestern France
}

Laurence Albert, Pierre Franck, Yann Gilles, Manuel Plantegenest

\section{To cite this version:}

Laurence Albert, Pierre Franck, Yann Gilles, Manuel Plantegenest. Impact of Agroecological Infrastructures on the Dynamics of Dysaphis plantaginea (Hemiptera: Aphididae) and Its Natural Enemies in Apple Orchards in Northwestern France. Environmental Entomology, 2017, 46 (3), pp.528-537. 10.1093/ee/nvx054. hal-01517228

\author{
HAL Id: hal-01517228 \\ https://hal.science/hal-01517228
}

Submitted on 26 May 2020

HAL is a multi-disciplinary open access archive for the deposit and dissemination of scientific research documents, whether they are published or not. The documents may come from teaching and research institutions in France or abroad, or from public or private research centers.
L'archive ouverte pluridisciplinaire HAL, est destinée au dépôt et à la diffusion de documents scientifiques de niveau recherche, publiés ou non, émanant des établissements d'enseignement et de recherche français ou étrangers, des laboratoires publics ou privés.

\section{()(1)(2)}

Distributed under a Creative Commons Attribution - ShareAlikel 4.0 International 
Albert et al.: Agroecological management in cider apple orchards

Environmental Entomology

Biological control - parasitoids and predators
Laurence ALBERT

Institut Français des Productions Cidricoles

La Rangées Chesnel

61500 SEES

France

Phone: +33 2.33.27.56.70

Fax: +33 2.33.27.49.51

E-mail: I albert5@yahoo.fr

\section{Impact of Agroecological Infrastructures on the Dynamics of}

\section{Dysaphis plantaginea Passerini (Hemiptera: Aphididae) and}

\section{its Natural Enemies in Apple Orchards in Northwestern}

\section{France}

Laurence ALBERT ${ }^{1}$, Pierre FRANCK ${ }^{3}$, Yann GILLES ${ }^{1}$, Manuel PLANTEGENEST²

1 Institut Français des Productions Cidricoles, La Rangée Chesnel, 61500 Sées, FRANCE

2 UMR1349 IGEPP, INRA/Agrocampus-Ouest/Université Rennes 1, 65 rue de Saint Brieuc, 35042

Rennes Cedex, FRANCE

${ }^{3}$ INRA Plantes \& Systèmes de culture Horticoles, F-84914 AVIGNON Cedex 9, FRANCE 


\section{ABSTRACT}

2

3 Apple orchard production is facing new environmental and societal challenges, resulting, in particular,

4 in strong pressure to reduce pesticide use. Cider-apple production, for which the perfect visual aspect of fruits is not a marketability imperative, offers good opportunities to study production systems that are developing new agronomic strategies, which could be subsequently extended to all apple-production types. Agroecological infrastructures play an important role in providing shelter, food resources or reproduction habitats to many arthropods. Consequently, setting-up agroecological infrastructures in the vicinity of or within orchards could increase natural enemy presence and thus improve the biological control of pests. In this study, we focused on Dysaphis plantaginea (Passerini), one of the major pests in apple orchards in Europe, which causes important economic production losses. During two years (2014 and 2015), we monitored the population dynamics of Dysaphis plantaginea, its natural enemies and mutualistic ants in commercial production cider-apple orchards. The influences of the cider-apple cultivar, insecticide use and distance to agroecological infrastructures (hedgerows and flower strips) were assessed. Our results suggest that flower strips favour an increase in natural enemy abundance in the vicinity of the orchards and could thus play an important role in the production system by improving the biological control of Dysaphis plantaginea.

\section{Keywords}

Biological control, cider-apple orchard, Dysaphis plantaginea, flower strip, hedgerow

In the second half of the $20^{\text {th }}$ century, the green revolution allowed an unprecedented increase in agricultural yields in developed countries. This yield increase was achieved by the generalization of agricultural mechanization and the use of synthetic pesticides and fertilizers. The green revolution resulted in agricultural landscape simplification (Robinson and Sutherland 2002, Benton et al. 2003) and produced numerous negative side effects on biodiversity (Krebs et al. 1999), human health (Lee et al. 2004, Simon et al. 2007) and the quality of soil and water (Moss 2008). Consequently, a change in the current agricultural paradigm and the development of more environmentally friendly agricultural practices are strongly required. 
Agroecology proposes to primarily base agricultural production on the mobilization of natural processes and the improvement of ecosystem services (e.g. pollination, nutrient cycling, biological control of pests) rather than on chemical inputs. In particular, promoting the natural control of pests would lead to insecticide use reduction. The resulting reduction of economic and environmental costs would contribute to increase farmer benefits and the environmental sustainability of agriculture (Tschumi et al. 2015). Various approaches have been proposed to improve pest biological control, including changes in practices (e.g. pesticide use reduction, accurate choice of cultivars) and establishing agroecological infrastructures within or in the vicinity of the crop (Haenke et al. 2009, Miñarro and Prida 2013). Agroecological infrastructures include hedgerows, flower strips, permanent grasslands and woodlands. They may provide pests and natural enemies with various beneficial functions, including suitable microclimatic conditions and refuge during adverse seasons (Landis et al. 2000). Thus, spiders, beetles and syrphids use them as overwintering areas (Collins et al. 2003, Sarthou et al. 2005, Pfiffner et al. 2013). Agroecological infrastructures also provide pollen and nectar resources that increase the longevity of parasitoids (Wäckers 2001, Berndt and Wratten 2005) and improve the fecundity of other insects (Schmale et al. 2001, Wäckers 2001, Winkler et al. 2006, Hogg et al. 2011, Laubertie et al. 2012, Rijn et al. 2013). Agroecological infrastructures also provide alternative prey for generalist predators when these resources are not available in the crop (Wyss 1996, Denys and Tscharntke 2002, Lavandero et al. 2005).

Northwestern France (i.e. Bretagne, Normandie and Pays de la Loire regions) is the number one ciderapple producing area in Europe. Cider-apple orchard cultivation is thus important in the local economy. The management of apple orchards is based on the intensive use of pesticides to control pests and pathogens (Sauphanor et al. 2009). Currently, farmers are under strong pressure to develop environmentally friendly protection strategies to address the new challenges imposed by society, and environmental laws. Because cider-apples are transformed, their perfect visual aspect is not a prerequisite of their marketability and fewer pesticide treatments are applied in cider-apple orchards than in orchards for fresh fruit production (approximately 15 vs 35 treatments per year). Consequently, cider-apple orchards offer an opportunity to develop and test protection strategies using less pesticide, which could subsequently be generalized.

Approximately 60 phytophagous arthropod species are considered to be apple pests (Jenser et al. 1999). The rosy apple aphid (RAA) Dysaphis plantaginea Passerini (Hemiptera: Aphididae), is among 
the most detrimental pests, causing significant economic losses by reducing yield (Blommers et al. 2004). The RAA is problematic not only in organic but also in conventional orchards due to its very low abundance threshold for economic damage, resulting in a low treatment threshold (i.e., as soon as the pest is detected) (Cross et al. 2007). As a consequence, an increase in insecticide resistance has been recorded (Delorme et al. 1998). Many recent studies have suggested that improving biological control efficiency could be an alternative to insecticides use to limit RAA populations (Hemptinne et al. 2003, Dib et al. 2010, Miñarro and Prida 2013). RAA is a host-alternating aphid species. Its primary host is the apple tree Malus domestica Borkh. (Rosales: Rosaceae), and its secondary hosts are plantain herbs Plantago spp, mainly P. lanceolata L. (Lamiales: Plantaginaceae) (Blommers, 1999). At the beginning of spring, eggs laid in autumn hatch on apple trees producing parthenogenically reproducing females (Lathrop 1928, Bonnemaison 1959, Blommers et al. 2004). Migration to a secondary host occurs from mid-June to July in the North of France. The aphids return to apple trees in autumn, where a sexual generation of oviparous females lays fertilized overwintering eggs on the apple trees. The economic losses caused by this leaf-roller aphid, which develops on the lower side of the leaves, are mainly due to the deformations caused to the fruits and growing shoots, decreasing the yield in the year of infestation, as well as in following years (Bonnemaison 1959, De Berardinis et al. 1994, Wilkaniec and Trzcinski, 1997, Blommers et al. 2004).

Several recent studies have focused on the community of natural enemies, which could play a role in the biological control of $D$. plantaginea during spring. In Europe, this community is mostly composed of syrphids, coccinellids, parasitoids (mainly Ephedrus sp - Hymenoptera: Braconidae), earwigs, spiders and Aphidoletes sp (Diptera: Cecidomyiidae) (Wyss et al. 1999, Miñarro et al. 2005, Dib et al. 2010, Arnaudov et al. 2013). The abundance of these natural enemies in orchards depends on the abundance of RAA prey (Dib et al. 2016) and on the intra-guild predation pressure (Rosenheim et al. 1993, Rosenheim et al. 1995, Korenko and Pekár 2010). Thus, while an increase in natural enemy abundance is expected to result in a decrease in RAA abundance, this trend may reverse when intra-guild predation is important (Snyder and Ives 2001). RAA population dynamics also depend on the presence of ants in the colony, as D. plantaginea is commonly attended by ants (Bonnemaison 1959, Stary 1970). Interactions between the ants and myrmecophilous aphids are beneficial for both arthropods: ants are supplied with sugar through aphids' honeydew whereas aphids improve their reproductive rate (El-Ziady and Kennedy 1956, Banks and Nixon 1958, Flatt and Weisser 2000) and are protected against natural 
enemies (Stadler and Dixon 1999, Yao et al. 2000, Kaneko 2003). Thus, the relationship between ants and $D$. plantaginea enhances the growth of aphid colonies by reducing aphid predation by their natural enemies (Stewart-Jones et al. 2008, Miñarro et al. 2010).

Several recent studies noted the potential of agroecological infrastructures to improve the biological control of $D$. plantaginea by favouring the natural enemy community (Dib et al. 2012, Miñarro and Prida 2013, Pfiffner et al. 2013). Knowledge about the distance at which agroecological infrastructures are operating would help to determine the required density needed to provide an efficient biological control. Indeed, several studies noted that the distance to agroecological infrastructures influenced parasitoids (Corbett and Rosenheim 1996, Lavandero et al. 2005), spiders (Miliczky and Horton 2005) and syrphids (Bowie 1999) abundances. Moreover, the link between the distance to agroecological infrastructures and natural enemy abundance is not systematically linear. For instance, Tylianakis et al. (2004) have shown that the proportion of the aphid Metopolophium dirhodum parasitised by Aphidius rhopalosiphi decreased exponentially with the distance to flower resources.

The present project aimed to determine the impact of two types of agroecological infrastructures - flower strips and hedgerows - on the abundance of arthropods interacting with $D$. plantaginea (natural enemies and ants) and its consequences on RAA population dynamics. The influence of the distance to these two types of agroecological infrastructures on arthropod dynamics was assessed in 14 cider-apple orchards in northwestern France, which exhibit a range of farming practices (cultivars, insecticide use). For this purpose, the arthropod populations (aphids, their main natural enemies and their mutualistic ants) were monitored in spring during two successive years.

\section{Materials and Methods}

\section{Monitored Cider-Apple Orchards}

Experiments were carried out in the spring and early summer in 2014 and 2015 in cider-apple orchards in seven locations in northwestern France (Fig. 1). The orchards were planted between 2010 and 2012 with three different cider-apple cultivars (three consecutive rows of each cultivar: Douce de l'Aventcov, Dabinett and Judor) grafted onto MM106 rootstock. The three cultivars differed in their vigour and precocity: Douce de l'Aventcov (DDA) was the most vigorous and precocious cultivar, Dabinett (DAB) was the less precocious cultivar and Judor (JUD) was intermediate. 
119 In each location, two contiguous orchards were studied that differed in regard to insecticide application 120 and in the agroecological infrastructures established (Table 1). Only five out of the seven locations were 121 monitored in 2014 (Fig. 1).

122

123

124

125

126

127

128

129

130

131

132

133

134

135

136

137

138

139

140

141

142

143

144

145

146

147

\section{Monitored Trees}

Approximately one-third of the trees were systematically monitored in each orchard (63 to 423 contiguous trees, depending on the considered orchard - Table 1). For each apple tree, the distance to the closest hedgerow (ranging from $5 \mathrm{~m}$ to $57 \mathrm{~m}$ ), the distance to the closest flower strip (ranging from $0 \mathrm{~m}$ to $63 \mathrm{~m}$ ) and the insecticide use were recorded, and the arthropod population dynamics were monitored.

The hedgerows were mainly composed of Carpinus betulus, Cornus sp, Corylus avellana, Viburnum sp, Sambucus nigra and Quercus pedonculata. All flower strips, established specifically for the study, included Centaurea cyanus, Silene vulgaris, Silene latifolia alba and Achillea millefolium.

\section{Assessment of Insecticide Toxicity to Beneficial Arthropods}

Calendars of the insecticide treatments in 2014 and 2015 were collected. The Environmental Impact Quotient (EIQ) was used to estimate the toxicity of each insecticide (https://nysipm.cornell.edu/eiq) to beneficial arthropods. EIQ assigns to each insecticide ingredient a score ranging from 5 to 125 according to its toxicity to beneficial arthropods (Kovach et al. 1992). We calculated the cumulative impact of the insecticides applied during the period of RAA presence in the apple trees (from March to July) in each orchard using the following formula:

$E I Q_{\text {field use rating }}=\sum\left(E I Q_{i} * R T_{i} *\right.$ \%active ingredient $\left._{i}\right)$,

where $E I Q_{i}$ is the EIQ value assigned to the active ingredient contained in the insecticide $i$ relative to beneficial arthropods, $R T_{i}$, the rate of insecticide $i$ use and \%active ingredient $t_{i}$ the percentage of active ingredient in the insecticide $i$. The $E / Q_{\text {field }}$ use rating ranged from 0 to 6.61 , depending on the year, the orchard and the cultivar (Table 1). The main active ingredients used against RAA in the cider orchard were flonicamid, acetamiprid and lambda cyhalothrin.

\section{Monitoring of Arthropod Population Dynamics}


148 The monitored trees were visually inspected to record the RAA abundance and the abundance of natural 149 enemies and ants within the RAA colonies. The mean height of the monitored trees was $3.4 \mathrm{~m}$ (SD 0.49 $150 \mathrm{~m})$. All terminal shoots of each monitored tree were inspected from the lowest branch up to a height of $1511.7 \mathrm{~m}$ for practical reasons. In 2014 and 2015, the trees were monitored every week from mid-April to 152 the end of June and every two weeks from mid-March to mid-April and during July (except in the two orchards ( $4 a$ and $4 b$ ) located at location 4 , where the RAA populations were recorded every two weeks 154 from April to July).

155

156

157 158

159

160

161

162

163

164

165

166

167

168

169

170

171

172

173

174

175

176

177

\section{Dysaphis plantaginea}

At each observation date, the total number of RAA individuals was counted on each monitored tree.

\section{Natural Enemies and Ants Observed in RAA Colonies}

At each observation date, the number and identity of each natural enemy type and the number of ants found within the RAA colonies were recorded and summed for each monitored tree. We also recorded the developmental stage of all of the observed natural enemies, as not all stages are involved in aphid control. In most cases, natural enemy identification was at the family level. Ants were not identified to the species level. However, we observed only Lasius niger and Formica sp.

\section{Data Analysis}

Dysaphis plantaginea

Three variables were considered to characterize the RAA population dynamics on each monitored tree and for each studied year to assess the different ecological processes:

(i) The presence/absence variable $(P A)$, indicating the RAA colonization process, was set to 0 when no RAA was observed at any date or to 1 when at least one RAA was observed on the monitored tree

(ii) The logarithm of the area under the curve $(\log A \cup C)$ of the tree population abundance, indicating in situ RAA population dynamics (survival and reproduction)

(iii) The presence duration (PD), in days (last date at which at least 1 aphid was observed minus the first date at which at least 1 aphid was observed), indicating the RAA emigration process

Natural Enemies and Ants 
178 Natural enemy dynamics and ants were only assessed on the monitored trees in which at least one RAA 179 was observed (i.e., a monitored tree where the RAA presence/absence was set to 1). The natural enemy 180 dynamics were characterized using the same variables as for RAA ( $P A$, logAUC and $P D)$ for each considered developmental stage (egg, larva, adult) of each taxon. A global variable (allNE) was also

182

183

184

185

186

187

188

189

190

191

192

193

194

195

196

197

198

199

200

201

202

203

204 was considered.

\section{was considered.}

205

Statistical Analyses

The main purpose of our study was to assess the influence of agroecological infrastructures on the three above variables characterizing RAA population dynamics. First, Generalized Linear Mixed Models (GLMM) were used to assess the influence of each considered factor (distance to the closest hedgerow, distance to the closest flower strip, EIQfield rating use and cultivar) on each RAA population dynamics variable $(P A, \log A \cup C$ and $P D)$ as well as its significance. Second, to assess in what extent factor effects could result from variations in natural enemy and ant population dynamics, the same GLMMs were fitted to the population dynamics variables associated to each natural enemy taxon and to ants but including as well the rosy apple aphid abundance (logAUC) as a supplementary explanatory variable. This allowed assessing how the dynamics of natural enemies and ants are impacted by agroecological infrastructures and other agricultural variables for a given level of rosy apple aphid abundance. Introducing the logAUC of RAA as a fixed factor was equivalent to analysing the influence of the factors under study on the abundance ratio between the natural enemies and aphids or between the ants and aphids. In all models two random factors were added, the orchard location and the studied year. All statistical analyses were carried out with the R 3.1.3 software (R core Team 2015) using the tree as the observation unit.

$P A$ were fitted assuming a binomial distribution, $\log A \cup C$ were fitted assuming a normal distribution and $P D$ were fitted using a Gamma distribution, regardless of the arthropod taxon. The mixed linear models were fitted using the Ime4 package, version 1.1-7 (Bates et al. 2015). A significance threshold of $p=0.05$

\section{Results}


The mean abundance of RAA observed per tree and per sampling date varied widely, depending on the studied year and studied orchard. For instance, in 2014, the mean number of RAA per tree and per sampling date ranged from 0.8 in orchard $3 b$ to 95.5 in orchard $7 a$ (Table 2 and Appendix B). Globally, the pest abundance was higher in 2015 than in 2014 in all orchards, except in orchards $4 a$ and $4 b$ (Appendix B).

The composition of the natural enemy community remained fairly stable from one year to the next (Table 2). The natural enemy community was dominated by Syrphidae ( $45 \%$ and $32 \%$ of the natural enemies observed in 2014 and 2015, respectively) and Coccinellidae (22\% and 36\% of the natural enemies observed in 2014 and 2015 , respectively), followed by Forficulidae (18\% and $15 \%$ of the natural enemies observed in 2014 and 2015, respectively) and Araneae (9\% of the natural enemies observed in both years). Few Chrysopidae, Hemiptera and Cantharidae were observed in both years and were not retained for the subsequent detailed statistical analyses (Table 2). Similarly few mummies were observed and the ratio of the mummy number to the RAA number never exceeded $0.2 \%$ whatever the considered year and orchard.

A large variation in the abundance of RAA, natural enemies and ants was observed among the orchards (Appendix B).

The natural enemy community composition varied strongly during the season. The community was dominated by Syrphidae early in the season and then by Coccinellidae and other natural enemies (Fig. 2). In both years, the RAA populations peaked between mid-May and the end of May.

\section{Observed Arthropod Taxa}

233

234 Table 3 provides a synthetic overview of the results of the GLMMs. Aphids and ants appeared to be more abundant in the vicinity of the hedgerows. On the contrary, hedgerows had in most cases no effect on the natural enemies. They only have a positive effect on the presence duration of Syrphidae larvae and of Syrphidae eggs and a negative effect on the presence duration of Coccinellidae larvae. On the contrary, aphids and ants were less abundant in the vicinity of the flower strips, while all of the natural 
enemies except the Araneae were positively impacted. All arthropods were generally more abundant on the Douce de l'Aventcov cultivar, followed by Judor, and were generally negatively impacted by the insecticide use (EIQtield use rating $)$. However, the insecticide effect on the Syrphidae and Coccinellidae was ambiguous. Indeed, the Syrphidae eggs ( $\log A U C$ and $P D)$ and Coccinellidae larvae $(P D)$ were positively impacted by the $E I Q_{\text {field use rating }}$ but the Syrphidae larvae $(P A)$ and the Coccinellidae eggs were negatively impacted by the $E / Q_{\text {field use rating }}(P A)$ (Appendix A). Finally, all natural enemy and ant abundances were positively impacted by aphid abundance. The results were generally consistent regardless of the variables used to describe the arthropod dynamics $(P A, \log A \cup C$ and $P D)$ or the considered natural enemy stage (egg, larva, adult). Detailed results by stage and variables are provided in Appendix A.

\section{Discussion}

\section{Main Findings}

This study was carried out under field and farming production conditions. Spatio-temporal variations regarding the abundance of aphids and of their natural enemies have long been reported to depend on farming practices (Marliac et al. 2015) and on climatic conditions (Hemptinne et al. 1994, Roy et al. 2002). Variations among locations and between years in population dynamics of RAA and their natural enemies are not surprising and were modelled as random factors to focus on the effects of farmer practices (insecticide treatment and cultivar choice) and of agroecological infrastructures (distances to the closest hedgerow and to the closest flower strip). All of these factors had an impact on population dynamics of aphids, of natural enemies and of ants. The tested factors appeared to be widely consistent among all natural enemy groups, suggesting that agricultural practices and agroecological infrastructures either favoured or disfavoured the entire community of natural enemies. While the cultivar and insecticide use intensity had a mostly similar influence on all arthropod abundances, the agroecological infrastructures had opposite effects on aphids and ants on the one hand and on natural enemies on the other hand. This result suggests that agroecological infrastructures actually impacted the level of RAA biological control by its natural enemies.

Analyses were carried out using three response variables characterizing arthropod population dynamics: presence probability, logarithm of the area under the curve and presence duration. Our hypothesis was that each variable was related to different ecological processes that could have been differentially influenced by the agricultural practices and agroecological infrastructures. However, in most cases in this study, the three variables were influenced in the same way by the agricultural 
270

271

272

273

274

275

276

277

278

279

280

281

282

283

284

285

286

287

288

289

290

291

292

293

294

295

296

297

298

299

practices and agroecological infrastructures, suggesting that environmental and agronomical practices had a similar influence on all of the population dynamics components.

\section{Structuration of the Arthropod Community}

Regardless of the year and orchard, Syrphidae and Coccinellidae were consistently the two most abundant groups of natural enemies, with Syrphidae being generally present earlier than Coccinellidae. These results are consistent with those of previous studies (Miñarro et al. 2005, Dib et al. 2010). However, the synchronization between the RAA and natural enemy dynamics varied between the studied years. The lowest RAA infestation level was observed in 2014, when RAA and natural enemy dynamics appeared to be the most synchronized. Indeed, in 2014, the increase of natural enemy abundance was concomitant to the increase of RAA population whereas in 2015 , the natural enemy abundance was at its lowest level when the RAA infestation was highest (Fig. 2).

Hymenoptera parasitoids were very rare in both year and in all orchards. The ratio of the number of mummies to the aphid number was much lower (always less than $0.2 \%$ in all years and orchards) than in previous surveys conducted in organic apple orchards (Dib et al. 2010: up to 6.9\%; Cruz de Boelpaepe et al. 1987: 3.3\%). However, other studies similarly reported the absence or a very low abundance of parasitism in RAA colonies (Miñarro et al. 2005, Brown and Mathews 2007). The low level of parasitism observed in our study could result from the high sensitivity of the hymenoptera parasitoid to insecticides (Theiling and Croft 1988). Another explanation could be an antagonist effect between ants and parasitoids as evidenced in previous studies (Völkl 1992, Stewart-Jones et al. 2008).

As expected, all natural enemies exhibited a positive response to RAA abundance either in their probability of presence (Coccinellidae, Araneae) or in both their probability of presence and abundance (Syrphidae, Forficulidae). This is not surprising, as natural enemies frequently aggregate in places where preys are abundant. In fact, previous studies showed that it is the case for Carabidae and Staphylinidae, (Bryan and Wratten 1984) or for Syrphidae (Tenhumberg and Poehling 1995, Miñarro et al. 2005).

Similarly, the presence probability, logarithm of the area under the curve and presence duration of ants responded positively to RAA abundance, which was expected considering the mutualistic relation between D. plantaginea and the two species of ants observed (Lasius niger L., Formica sp.) (Flatt and Weisser 2000, Stewart-Jones et al. 2008). 
This dependence of ant and natural enemy abundances on RAA abundance supported our choice to include RAA abundance as a factor in the models (through the $\log A \cup C$ of RAA). In this way, we were able to analyse the direct effects of farmer practices and agroecological infrastructures on natural enemies and ants.

\section{Practices and Cultivar Influence}

Impact of Insecticides on RAA and Natural Enemy Population Dynamics

As expected, we observed a decrease in the probability and duration of RAA presence with an increase

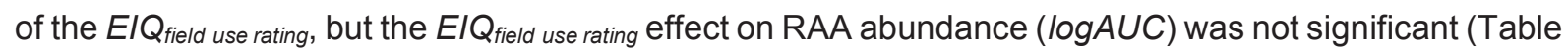
3 and Appendix A). Such an effect is especially expected in leaf-curling aphids, such as $D$. plantaginea. Indeed, aphids are more vulnerable to insecticides in the first phase of colonization, resulting in a reduction of the colonization success and hence on the presence probability. The aphid vulnerability further decreases while the colony size increases because the rolling-up of leaves provides them with protection against insecticides (Cross et al. 2007). Moreover, the negative effect of insecticides on natural enemies might further reduce aphid biological control. A negative effect of insecticide treatments was observed on the presence probability of alINE and on their abundance $(\log A U C)$. This negative effect was significant on the presence probability of Syrphidae larvae, of Syrphidae eggs and of Coccinellidae eggs, as well as on the Forficulidae abundance and on Araneae presence duration. Insecticide treatments applied early in the season seem to be the most efficient to control the development of $D$. plantaginea colonies. Insecticide applications after the leaf curling, would impact more strongly the natural enemies than aphids. High $E I Q_{\text {field use rating }}$ also reduced ant abundance in RAAinfested trees, suggesting that insecticide treatments also negatively impact the ant population.

\section{Effect of Cultivar on RAA and Natural Enemy Population Dynamics}

A strong impact of the cultivar was observed in our study and its effect varied whether we considered the presence probability and the presence duration of RAA and natural enemies or the abundance of RAA and natural enemies (except for the Dabinett cultivar, which always exhibited the lowest presence probability, abundance and presence duration of RAA and natural enemies). Douce de l'Avent $t_{c o v}$ had the highest presence probability and presence duration of RAA and natural enemies (AIINE), followed by Judor. For the RAA, this ranking matches cultivars ranked according to precocity. Douce de l'Avent cov 
was the most precocious cultivar, followed by Judor, with Dabinett being the latest cultivar. Miñarro and Dapena, (2007) still showed that early-leafing apple cultivars were more infested and damaged by RAA than late-leafing ones. We can suppose that the same process operates for natural enemies. However, a different cultivar ranking was obtained when the abundance of RAA and natural enemies was considered, switching between cultivars: Judor had the higher abundance of RAA and of natural enemies (AIINE), followed by Douce de l'Aventcov. This apparent inconsistency could result from an interaction between the colonization rate and treatment frequency. In fact, the most heavily colonized cultivar (Douce de l'Aventcov) was also the earliest one treated with insecticides, resulting in low abundances of both aphids and natural enemies throughout the season.

\section{Hedgerows Favour RAA Populations}

Unexpectedly, hedgerows appeared to be consistently beneficial to RAA populations. Indeed, hedgerow proximity had a positive impact on all of the RAA population dynamics parameters. This hedgerow effect may result from either direct effects on the RAA population dynamics, from indirect effects through its influence on mutualistic or antagonist arthropods, or both. The vicinity of the hedgerow may influence the flight behaviour of arthropods by modifying the wind speed and turbulences (Pasek 1988), which could result in the accumulation of insects on the leeward side of the hedgerow (Lewis 1965, Grüebler et al. 2008). Such an effect could result in a higher colonization rate by RAA of apple trees situated in the vicinity of hedgerows.

Hedgerows may also indirectly favour aphids by favouring mutualistic ants possibly by providing a suitable nesting habitat. Indeed, the ant presence probability increased with the proximity to the hedgerow in our study. To our knowledge, very few studies have assessed hedgerow influence on ants. Stutz and Entling (2011) found no effect of a woody habitat in the surrounding landscape on ant presence on cherry trees, but Armbrecht and Perfecto (2003) reported a dramatic decrease of twignesting ants with an increase in the distance to forest fragments in coffee plantations in Mexico.

Finally, the proximity of hedgerows may modify the arthropods interaction network. For instance, the presence of a hedgerow could reduce RAA biocontrol by increasing the intra-guild predation between natural enemies (Straub et al. 2008) or by diverting natural enemies from pests by offering them alternative prey (Kozar et al. 1994, Koss and Snyder 2005, Symondson et al. 2006). Moreover, as the presence of ants is higher in the hedgerow vicinity, the protection they provide to RAA against their 
360

361

362

363

364

365

366

367

368

369

370

371

372

373

374

375

376

377

378

379

380

381

382

383

384

385

386

387

388

389

natural enemies could be enhanced. Contrary to previous studies (Altieri and Schmidt 1986, Miñarro and Prida 2013), few hedgerow-distance effects on natural enemy occurrence or abundance in aphid colonies were found in our study. The only significant effects were the decrease of the presence probability and of the presence duration of Coccinellidae larvae and the increase of the presence duration of Syrphidae larvae and Syrphidae eggs in the vicinity of the hedgerow.

\section{Flower Strips Reduce RAA Populations and Increase Natural Enemy Abundance}

Contrary to hedgerows, flower strips had a negative impact on the RAA populations in our study. Indeed, the presence probability, the abundance and the presence duration of RAA all decreased with flower strips proximity. A direct effect of flower strips on aphids was very unlikely. We then assumed that flower strips exerted an indirect effect through their influence on the natural enemies and/or on ants. Indeed, Wyss, (1995) and Wyss et al. (1995) showed that introducing flower strips in apple orchards resulted in an increase in natural enemy abundance (Chrysopidae, Coccinellidae, Araneae). Similarly, in our study, the abundance $(\log A U C)$ and presence duration of natural enemies (alINE) increased in proximity to flower strips. More specifically, the presence probability and abundance of Syrphidae (eggs and larvae), presence probability of Coccinellidae (eggs and larvae) and abundance of Forficulidae decreased significantly with the distance to flower strips. This increase of presence and/or of abundance of natural enemies could enhance aphid biological control in the vicinity of flower strips. Hogg et al. (2011) showed that floral resources enhanced aphid suppression by the hoverfly Eupeodes fumipennis in a California lettuce field. In addition, the negative influence of flower strips on aphid populations could also be amplified by their negative effect on the ant presence probability. Nagy et al. (2013) showed that applying artificial sugar sources in apple orchards resulted in a reduction of the number of ant-attended D. plantaginea colonies and in an increase in natural enemy pressure. Similarly, by providing alternative sugar resources, flower strips could distract ants from aphid attendance. Katayama et al. (2013) showed that extrafloral nectar was more attractive to ants than aphid honeydew. In total, our results suggest that flower strips are beneficial to natural enemies and reduce ant attendance that could account for the observed reduction of $D$. plantaginea infestation in cider-apple trees located in the vicinity of flower strips.

\section{Conclusion}


390

391

392

393

394

395

396

397

398

399

400

401

402

403

404

405

406

407

408

409

410

411

412

413

414

415

416

417

This study showed an impact of the distance to agroecological infrastructures on $D$. plantaginea dynamics in cider-apple orchards. Hedgerows increased the RAA infestation level. This could result from an indirect effect due to modifications in the RAA interactions network with other arthropods. Indeed, our results showed an increase in the presence of mutualistic ants and a decrease in RAA natural enemy abundance in the vicinity of hedgerow. On the contrary, flower strips appeared unfavourable to $D$. plantaginea. Again it could result from indirect effect due to an increase in natural enemy abundance and a decrease of ant presence in the RAA colony. Additionally, we confirmed a strong influence of cultivars and of insecticide use intensity on $D$. plantaginea dynamics.

\section{Acknowledgments}

We thank A. Taillade and A. Quero for data collection and the farmers who allowed us to access their orchards. We thank Sylvaine Simon for her help in the characterization of agroecological infrastructure. We thank two anonymous reviewers for their useful comments on a previous version of this manuscript. The work was supported by ANRT, UNICID, Région Bretagne, Région Normandie and the Ministère de l'Agriculture, de l'agroalimentaire et de la forêt (CASDAR). This project is linked to the PEERLESS project (ANR-12-AGRO-0006) and to the "Verger Cidricole de Demain" CASDAR project. 
Banks, B. Y. C. J., and H. L. Nixon. 1958. Effects of the ant, Lasius niger L., on the feeding and excretion of the bean aphid, Aphis fabae Scop.. J. Exp. Biol., 35(4): 703-711.

Barzman, M., and S. Dachbrodt-Saaydeh. 2011. Comparative analysis of pesticide action plans in five European countries. Pest management science, 67(12): 1481-1485.

Bates, D., M. Mächler, B. Bolker, and S. Walker. 2015. Fitting linear mixed-effects models using Ime4. Journal of Statistical Software, 67(1), 1-48.

Benton, T. G., J. A. Vickery, and J. D. Wilson. 2003. Farmland biodiversity : is habitat heterogeneity the key?. Trends Ecol. Evol., 18(4): 182-188.

Berndt, L. A., and S. D. Wratten. 2005. Effects of alyssum flowers on the longevity, fecundity, and sex ratio of the leafroller parasitoid Dolichogenidea tasmanica. Biol. Control, 32(1): 65-69.

Biddinger, D. J., T. W. Leslie, and N. K. Joshi. 2014. Reduced-risk pest management programs for Eastern US peach orchards: effects on arthropod predators, parasitoids, and select pests. J. Econ. Entomol., 107(3): 1084-1091.

Blommers, L. H. M. 1999. Probing the natural control of rosy aphid Dysaphis plantaginea (Hemiptera: Aphididae). IOBC-WPRS Bulletin 22(7): 53-56.

Blommers, L. H. M., H. H. M. Helsen, and F. W. N. M. Vaal. 2004. Life history data of the rosy apple aphid Dysaphis plantaginea (Pass.) (Homopt., Aphididae) on plantain and as migrant to apple. J. Pest Sci., 77(3) : 155-163.

Bonnemaison, L. 1959. Le puceron cendré du pommier (Dysaphis plantaginea Pass.) Morphologie et biologie - Méthodes de lutte. Annales de l'Institut National de la Recherche Agronomique, Série C, 438 Epiphyties 3: 257-322.

Bowie, M. H. 1999. Effects of distance from field edge on aphidophagous insects in a wheat crop and 440 observations on trap design and placement. International Journal of Pest Management, 45(1): 69-73.

441 Brown, M. W., and C. R. Mathews. 2007. Conservation Biological Control of Rosy Apple Aphid, 442 Dysaphis plantaginea (Passerini), in Eastern North America. Environ. Entomol., 36(5): 1131-1139.

443 Bryan, K. M., and S. D. Wratten. 1984. The responses of polyphagous predators to prey spatial 444 heterogeneity: aggregation by carabid and staphylinid beetles to their cereal aphid prey. Ecol. Entomol., 445 9(3): 251-259. 
Collins, K. L., N. D. Boatman, A. Wilcox, and J. M. Holland. 2003. Effects of different grass treatments used to create overwintering habitat for predatory arthropods on arable farmland. Agric. Ecosyst. Environ., 96(1): 59-67.

Corbett, A., and J. A. Rosenheim. 1996. Impact of a natural enemy overwintering refuge and its interaction with the surrounding landscape. Ecol. Entomol., 21(2): 155-164.

Cross, J. V., S. Cubison, A. Harris, and R. Harrington. 2007. Autumn control of rosy apple aphid, Dysaphis plantaginea (Passerini), with aphicides. Crop Prot., 26(8) : 1140-1149.

Cruz de Boelpaepe, M.O., N. M. Filipe, and V. C. Afonso. 1987. Dynamique des populations aphidiennes en verger de pommiers. Leurs fluctuations saisonnières dans la province de Beira-Baixa (Portugal) en fonction des facteurs de l'environnement. Phytoma-La Défense des Végétaux 246: 5-16. De Berardinis, E., P. Baronio and J. Baumgärtner. 1994. The effect of aphid (Dysaphis plantaginea Pass., Hom.,Aphididae) feeding on apple fruit growth. Ecol. Modell. 72(1-2) : 115-127.

Delorme, R., D. Auge, P. Touton, C. Vergnet, and F. Villatte. 1998. La résistance des pucerons aux insecticides. Enquêtes 1997. In: Proceedings of the 1st Colloque Transnational sur les Luttes Biologiques, Intégrées et Raisonnées; Lille, France.

Denys, C., and T. Tscharntke. 2002. Plant-insect communities and predator-prey ratios in field margin strips, adjacent crop fields, and fallows. Oecologia, 130(2): 315-324.

Dib, H., S. Simon, B. Sauphanor, and Y. Capowiez. 2010. The role of natural enemies on the population dynamics of the rosy apple aphid, Dysaphis plantaginea Passerini (Hemiptera: Aphididae) in organic apple orchards in south-eastern France. Biol. Control, 55(2): 97-109.

Dib, H., G. Libourel, and F. Warlop. 2012. Entomological and functional role of floral strips in an organic apple orchard: Hymenopteran parasitoids as a case study. J. Insect Conserv., 16(2): 315-318.

Dib, H., B. Sauphanor, and Y. Capowiez. 2016. Effect of management strategies on arthropod communities in the colonies of rosy apple aphid, Dysaphis plantaginea Passerini (Hemiptera: Aphididae) in south-eastern France. Agric. Ecosyst. Environ., 216: 203-206.

El-Ziady, S., and J. S. Kennedy. 1956. Beneficial effects of the common garden ant, Lasius niger L., on the black bean aphid, Aphis fabae Scopoli. Proc. R. Entomol. Soc. Lond. Ser. A Gen. Entomol., 35(13): $61-65$. 
Flatt, T., and W. W. Weisser. 2000. The effects of mutualistic ants on aphid life history traits. Ecology, 81(12): 3522-3529.

Grüebler, M. U., M. Morand, and B. Naef-Daenzer. 2008. A predictive model of the density of airborne insects in agricultural environments. Agric. Ecosyst. Environ., 123(1): 75-80.

Haenke, S., B. Scheid, M. Schaefer, T. Tscharntke, and C. Thies. 2009. Increasing syrphid fly diversity and density in sown flower strips within simple vs. complex landscapes. J. Appl. Ecol., 46(5): $1106-1114$.

Hemptinne, J. L., P. Guillaume, C. Gaspar, and A. F. G. Dixon. 1994. Integrated control programme for the apple aphid, Dysaphis plantaginea Passerini (Homoptera: Aphididae): forecasting seasonal and yearly changes in abundance. Mededelingen-Faculteit Landbouwkundige en Toegepaste Biologische Wetenschappen Universiteit Gent (Belgique).

Hemptinne, J. L., A. F. G. Dixon, and E. Wyss. 2003. Biological control of the rosy apple aphid, Dysaphis plantaginea (Passerini) (Homoptera: Aphididae): Learning from the ecology of ladybird beetles. Biology, Ecogology and Behaviour of Aphidophagous Insects Arquipélago - Life and Marine Sciences S5, Université des Açores, Portugal: 33-41.

Hogg, B. N., E. H. Nelson, N. J. Mills, and K. M. Daane. 2011. Floral resources enhance aphid suppression by a hoverfly. Entomol. Exp. Appl., 141(2): 138-144.

Jenser, G., K. Balázs, C. Erdélyi, A. Haltrich, F. Kádár, F. Kozár, V. Marko, V. Racz, and F. Samu. 1999. Changes in arthropod population composition in IPM apple orchards under continental climatic conditions in Hungary. Agric. Ecosyst. Environ., 73(2): 141-154.

Kaneko, S. 2003. Impacts of two ants, Lasius niger and Pristomyrmex pungens (Hymenoptera: Formicidae), attending the brown citrus aphid, Toxoptera citricidus (Homopera: Aphididae), on the parasitism of the aphid by primary parasitoid, Lysiphlebus japonicus (Hymenoptera). Appl. Entomol. Zool., 38(3): 347-357.

Katayama, N., D. H. Hembry, M. K. Hojo, and N. Suzuki. 2013. Why do ants shift their foraging from extrafloral nectar to aphid honeydew?. Ecol. Res., 28(5): 919-926.

Korenko, S., and S. Pekár. 2010. Is there intraguild predation between winter-active spiders (Araneae) on apple tree bark? Biol. Control, 54(3): 206-212. 
502

503

504

505

506

507

508

509

510

511

512

513

514

515

516

517

518

519

520

521

522

523

524

525

526

527

528

529

Koss, A. M., and W. E. Snyder. 2005. Alternative prey disrupt biocontrol by a guild of generalist predators. Biol. Control, 32(2): 243-251.

Kovach, J., C. Petzoldt, J. Degni, and J. Tette. 1992. A method to measure the environmental impact of pesticides. New York's Food and Life Science Bulletin, 139: 1-8.

Kozar, B. F., M. W. Brown, and G. Lightner. 1994. Spatial distribution of homopteran pests and beneficial insects in an orchard and its connection with ecological plant protection. J. Appl. Entomol., 117(1-5): 519-529.

Krebs, J. R., J. D. Wilson, R. B. Bradbury, and G. M. Siriwardena. 1999. The second Silent Spring?. Nature, 400(6745): 611-612.

Landis, D. A., S. D. Wratten, and G. M. Gurr. 2000. Habitat management to conserve natural enemies of arthropod pests. Annu. Rev. Entomol., 45(1): 175-201.

Lathrop, F.H. 1928. The biology of apple aphids. The Ohio Journal of Science 28: 177-204.

Laubertie, E. A., S. D. Wratten, and J. L. Hemptinne. 2012. The contribution of potential beneficial insectary plant species to adult hoverfly (Diptera: Syrphidae) fitness. Biol. Control., 61(1): 1-6.

Lavandero, B., S. Wratten, P. Shishehbor, and S. Worner. 2005. Enhancing the effectiveness of the parasitoid Diadegma semiclausum (Helen): Movement after use of nectar in the field. Biol. Control, 34(2), 152-158.

Lee, W. J., J. A. Hoppin, A. Blair, J. H. Lubin, M. Dosemeci, S. Dale, and M. C. R. Alavanja. 2004. Cancer Incidence among Pesticide Applicators Exposed to Alachlor in the Agricultural Health Study. Am. J. Epidemiol, 159(4): 373-380.

Lewis, T. 1965. The effects of an artificial windbreak on the aerial distribution of flying insects. Ann. of Appl. Biol., 55: 503-512.

Marliac, G., S. Penvern, J. M. Barbier, F. Lescourret, and Y. Capowiez. 2015. Impact of crop protection strategies on natural enemies in organic apple production. Agron. Sustain. Dev., 35(2): 803813.

Miliczky, E. R., and D. R. Horton. 2005. Densities of beneficial arthropods within pear and apple orchards affected by distance from adjacent native habitat and association of natural enemies with extraorchard host plants. Biol. Control, 33(3): 249-259. 
530

531

532

533

534

535

536

537

538

539

540

541

542

543

544

545

546

547

548

549

550

551

552

553

554

555

556

557

Miñarro, M., J.L. Hemptinne, and E. Dapena. 2005. Colonization of apple orchards by predators of Dysaphis plantaginea: sequential arrival, response to prey abundance and consequences for biological control. BioControl, 50(3): 403-414.

Miñarro, M., and E. Dapena. 2007. Resistance of apple cultivars to Dysaphis plantaginea (Hemiptera: Aphididae): role of tree phenology in infestation avoidance. Environ. Entomol., 36(5): 1206-1211.

Miñarro, M., and E. Prida. 2013. Hedgerows surrounding organic apple orchards in north-west Spain: potential to conserve beneficial insects. Agr. Forest Entomol., 15(4): 382-390.

Miñarro, M., G. Fernández-Mata, and P. Medina. 2010. Role of ants in structuring the aphid community on apple. Ecol. Entomol., 35(2): 206-215.

Moss, B. 2008. Water pollution by agriculture. Philos. Trans. R. Soc. Lond. B Biol. Sci., 363(1491): 659 $-666$.

Nagy, C., J. V. Cross, and V. Markó. 2013. Sugar feeding of the common black ant, Lasius niger (L.), as a possible indirect method for reducing aphid populations on apple by disturbing ant-aphid mutualism. Biol.I Control, 65(1): 24-36.

Pasek, J. E. 1988. Influence of wind and windbreaks on local dispersal of insects. Agric. Ecosyst. Environ., 22: 539-554.

Pfiffner, L., H. J. Schärer, and H. Luka. 2013. Functional biodiversity to improve pest control in organic cropping systems. Agric. Ecosyst. Environ., 78(3): 215-222.

R Core Team 2015. R: A language and environment for statistical computing. R Foundation for 565 Statistical Computing, Vienna, Austria. http://www.R-project.org/

Rijn, C. J. Van, J. Kooijman, and F. L. Wäckers. 2013. The contribution of floral resources and honeydew to the performance of predatory hoverflies (Diptera: Syrphidae). Biol. Control, 67(1): 32-38. Robinson, R. A., and W. J. Sutherland. 2002. Post-war changes in arable farming and biodiversity in Great Britain. J. Appl. Ecol., 39(1): 157-176.

Rosenheim, J. A., L. R. Wilhoit, and C. A. Armer. 1993. Influence of intraguild predation among generalist insect predators in the suppression of an herbivore population. Oecologia, 96(3): 439-449.

Rosenheim, J. A., H. K. Kaya, L. E. Ehler, J. J. Marois, and B. A. Jaffret. 1995. Intraguild predation among biological-control Agents: theroy and evidence. Biol. Control, 5(3): 303-335. 
558

559

560

561

562

563

564

565

566

567

568

569

570

571

572

573

574

575

576

577

578

579

580

581

582

583

584

585

Roy, L. E., J. Brodeur, and C. Cloutier. 2002. Relationship between temperature and developmental rate of Stethorus punctillum (Coleoptera: Coccinellidae) and its prey Tetranychus mcdanieli (Acarina: Tetranychidae). Environ. Entomol., 31(1): 177-187.

Sarthou, J. P., A. Ouin, F. Arrignon, G. Barreau, and B. Bouyjou. 2005. Landscape parameters explain the distribution and abundance of Episyrphus balteatus (Diptera: Syrphidae). Eur. J. Entomol., 102(3): 539-545.

Sauphanor, B., S. Simon, C. Boisneau, Y. Capoview, R. Rieux, J.C. Bouvier, H. Defrance, C. Picard, and J.F. Toubon. 2009. Protection phytosanitaire et biodiversité en agriculture biologie. Le cas des vergers de pommiers. Innovations Agronomiques, 4: 217-228.

Schmale, I., F. L. Wäckers, C. Cardona, and S. Dorn. 2001. Control Potential of Three Hymenopteran Parasitoid Species against the Bean Weevil in Stored Beans: The Effect of Adult Parasitoid Nutrition on Longevity and Progeny Production. Biol. Control, 21(2): 134-139.

Simon, S., H. Defrance, and B. Sauphanor. 2007. Effect of codling moth management on orchard arthropods. Agric. Ecosyst. Environ., 122(3): 340-348.

Simon, S., L. Brun, J. Guinaudeau, and B. Sauphanor. 2011. Pesticide use in current and innovative apple orchard systems. Agron. Sustain. Dev, 31(3): 541-555.

Snyder, W. E., and A. R. Ives. 2001. Generalist Predators Disrupt Biological Control by a Specialist Parasitoid. Ecology, 82(3): 705.

Stadler, B., and A. F. G. Dixon. 1999. Ant attendance in aphids: why different degrees of myrmecophily?. Ecol. Entomol., 24(3): 363-369.

Starỳ, P. 1970. Biology of Aphid Parasites (Hymenoptera: Aphidiidae). Series entomologica Vol. 6.

Stewart-Jones, A., T. W. Pope, J. D. Fitzgerald, and G. M. Poppy. 2008. The effect of ant attendance on the success of rosy apple aphid populations, natural enemy abundance and apple damage in orchards. Agr. Forest Entomol., 10(1): 37-43.

Straub, C. S., D. L. Finke, and W. E. Snyder. 2008. Are the conservation of natural enemy biodiversity and biological control compatible goals?. Biol. Control, 45(2): 225-237.

Stutz, S., and M. H. Entling. 2011. Effects of the landscape context on aphid-ant-predator interactions on cherry trees. Biol. Control., 57(1): 37-43. 
586

587

588

589

590

591

592

593

594

595

596

597

598

599

600

601

602

603

604

605

606

607

608

609

610

611

612

613

Symondson, W. O. C., S. Cesarini, P. W. Dodd, G. L. Harper, M. W. Bruford, D. M. Glen, C. W. Wiltshire, and J. D. Harwood. 2006. Biodiversity vs. biocontrol: positive and negative effects of alternative prey on control of slugs by carabid beetles. Bull. Entomol Res., 96(6): 637-645.

Tenhumberg, B., and H. Poehling. 1995. Syrphids as natural enemies of cereals aphids in Germany: Aspects of their biology and efficacy in different years and regions. Agric. Ecosyst. Environ., 52(1): 3943.

Theiling, K. M., and B. A. Croft. 1988. Pesticide side-effects on arthropod natural enemies: a database summary. Agric. Ecosyst. Environ., 21(3-4): 191-218.

Tschumi, M., M. Albrecht, M. H. Entling, and K. Jacot. 2015. High effectiveness of tailored flower strips in reducing pests and crop plant damage. Proc. R. Soc. Lond. B Biol. Sci., 282: 20151369.

Tylianakis, J. M., R. K. Didham, and S. D. Wratten. 2004. Improved fitness of aphid parasitoids receiving resource subsidies. Ecology, 85(3): 658-666.

VölkI, W. 1992. Aphids or their parasitoids: who actually benefits from ant-attendance?. J. Anim. Ecol., 61: $273-281$.

Wäckers, F. L. 2001. A comparison of nectar- and honeydew sugars with respect to their utilization by the hymenopteran parasitoid Cotesia glomerata. J. Insect Physiol., 47(9): 1077-1084.

Wilkaniec, B., and P. Trzcinski. 1997. Effect of rosy apple aphid, Dysaphis plantaginea (Pass.) (Homoptera; Aphididae), feeding on fruits of the Primula variety. Progress in Plant Protection 37: $36-$ 39.

Winkler, K., F. Wäckers, G. Bukovinszkine-Kiss, and J. van Lenteren. 2006. Sugar resources are vital for Diadegma semiclausum fecundity under field conditions. Basic and Applied Ecology, 7(2): 133 $-140$.

Wyss, E. 1995. The effects of weed strips on aphids and aphidophagous predators in an apple orchard. Entomol. Exp. Appl., 75(1): 43-49.

Wyss, E., U. Niggli, and W. Nentwig. 1995. The impact of spiders on aphid populations in a stripmanaged apple orchard. J. Appl. Entomol., 119(1-5): 473-478.

Wyss, E. 1996. The effects of artificial weed strips on diversity and abundance of the arthropod fauna in a Swiss experimental apple orchard. Agric. Ecosyst. Environ., 60(1): 47-59. 
614 Wyss, E., M. Villiger, J. L. Hemptinne, and H. Müller-Schärer. 1999. Effects of augmentative releases 615 of eggs and larvae of the ladybird beetle, Adalia bipunctata, on the abundance of the rosy apple aphid, 616 Dysaphis plantaginea, in organic apple orchards. Entomol. Exp. Appl., 90(2): 167-173.

617 Yao, I., H. Shibao, and S. Akimoto. 2000. Costs and benefits of ant attendance to the drepanosiphid 618 aphid Tuberculatus quercicola. OIKOS, 89(1): 3-10. 


\section{TABLE}

Table 1: Main characteristics of the 14 studied cider-apple orchards. Two contiguous orchards (referred by a or $b$ ) have been monitored in each location (referred by number). In each orchard, 3 cider-apple cultivars were planted (DDA = Douce de l'Aventcov cultivar, DAB = Dabinett cultivar and JUD= Judor cultivar).

The Environmental Impact Quotient (EIQ) of each insecticide applied during the RAA presence on the apple trees was used to assess the cumulative toxicity of insecticides used in each orchard each year (E/Q field use rating). *: only 63 trees monitored in 2014; **:only 425 trees monitored in 2014. NA means Not Applicable.

\begin{tabular}{|c|c|c|c|c|c|c|c|c|c|c|c|c|c|c|c|}
\hline \multirow{2}{*}{\multicolumn{2}{|c|}{$\begin{array}{l}\text { Location } \\
\text { Orchard }\end{array}$}} & \multicolumn{2}{|c|}{1} & \multicolumn{2}{|c|}{2} & \multicolumn{2}{|c|}{3} & \multicolumn{2}{|c|}{4} & \multicolumn{2}{|c|}{5} & \multicolumn{2}{|c|}{6} & \multicolumn{2}{|c|}{7} \\
\hline & & $1 a$ & $1 b$ & $2 a$ & $2 b$ & $3 a$ & $3 b$ & $4 a$ & $4 b$ & $5 a$ & $5 b$ & $6 a$ & $6 b$ & $7 a$ & $7 \mathrm{~b}$ \\
\hline \multicolumn{2}{|l|}{ Year of planting } & 2010 & 2010 & 2012 & 2012 & 2011 & 2011 & 2012 & 2012 & 2011 & 2011 & 2011 & 2011 & 2010 & 2010 \\
\hline $\begin{array}{l}\text { Density of plantir } \\
\text { by number of trees } \\
\text { (planting distance be } \\
\text { rows }{ }^{*} \text { planting dista } \\
\text { within rows) }\end{array}$ & $\begin{array}{l}\text { g } \\
\text { ha } \\
\text { ween } \\
\text { ice }\end{array}$ & $\begin{array}{c}774 \\
\left(5.5^{\star} 2.3\right)\end{array}$ & $\begin{array}{c}774 \\
\left(5.5^{\star} 2.3\right)\end{array}$ & $\begin{array}{c}495 \\
\left(6.5^{\star} 3\right)\end{array}$ & $\begin{array}{c}774 \\
\left(5.5^{\star} 2.3\right)\end{array}$ & $\begin{array}{c}774 \\
\left(5.5^{\star} 2.3\right)\end{array}$ & $\begin{array}{c}774 \\
\left(5.5^{\star} 2.3\right)\end{array}$ & $\begin{array}{c}495 \\
\left(6.5^{\star} 3\right)\end{array}$ & $\begin{array}{c}774 \\
\left(5.5^{\star} 2.3\right)\end{array}$ & $\begin{array}{c}1000 \\
\left(5.3^{*} 2\right)\end{array}$ & $\begin{array}{c}1000 \\
\left(5.3^{*} 2\right)\end{array}$ & $\begin{array}{c}774 \\
\left(5.5^{\star} 2,3\right)\end{array}$ & $\begin{array}{c}774 \\
\left(5.5^{\star} 2.3\right)\end{array}$ & $\begin{array}{c}774 \\
\left(5.5^{\star} 2.3\right)\end{array}$ & $\begin{array}{c}774 \\
\left(5.5^{\star} 2.3\right)\end{array}$ \\
\hline Number of monitorec & trees & 198 & 198 & 153 & 153 & 162 & 162 & $117^{*}$ & $117^{*}$ & 234 & 234 & 279 & 279 & $270^{* *}$ & $270^{* *}$ \\
\hline EIQfield use rating 2014 & DDA & 0.61 & 5.58 & 0 & 1.20 & 0.35 & 0.35 & 0 & 0 & NA & NA & NA & NA & 0 & 0.29 \\
\hline in (for each apple & $\mathrm{DAB}$ & 0.61 & 5.58 & 0 & 1.20 & 0.35 & 0.35 & 0 & 0 & NA & NA & NA & NA & 0 & 2.09 \\
\hline cultivar) & JUD & 0.61 & 5.58 & 0 & 1.20 & 0.35 & 0.35 & 0 & 0 & NA & NA & NA & NA & 0 & 0 \\
\hline EIQfield use rating 2015 & DDA & 0.67 & 6.61 & 0 & 0 & 0 & 2.80 & 0 & 1.16 & 0.087 & 0.33 & 0 & 6.81 & 0 & 0.24 \\
\hline in (for each apple & $\mathrm{DAB}$ & 0.67 & 6.61 & 0 & 0 & 0 & 1.60 & 0 & 1.16 & 0.087 & 0.33 & 0 & 4.67 & 0 & 0.35 \\
\hline cultivar) & JUD & 0.67 & 6.61 & 0 & 0 & 0 & 2.80 & 0 & 1.16 & 0.087 & 0.33 & 0 & 6.61 & 0 & 0.35 \\
\hline
\end{tabular}




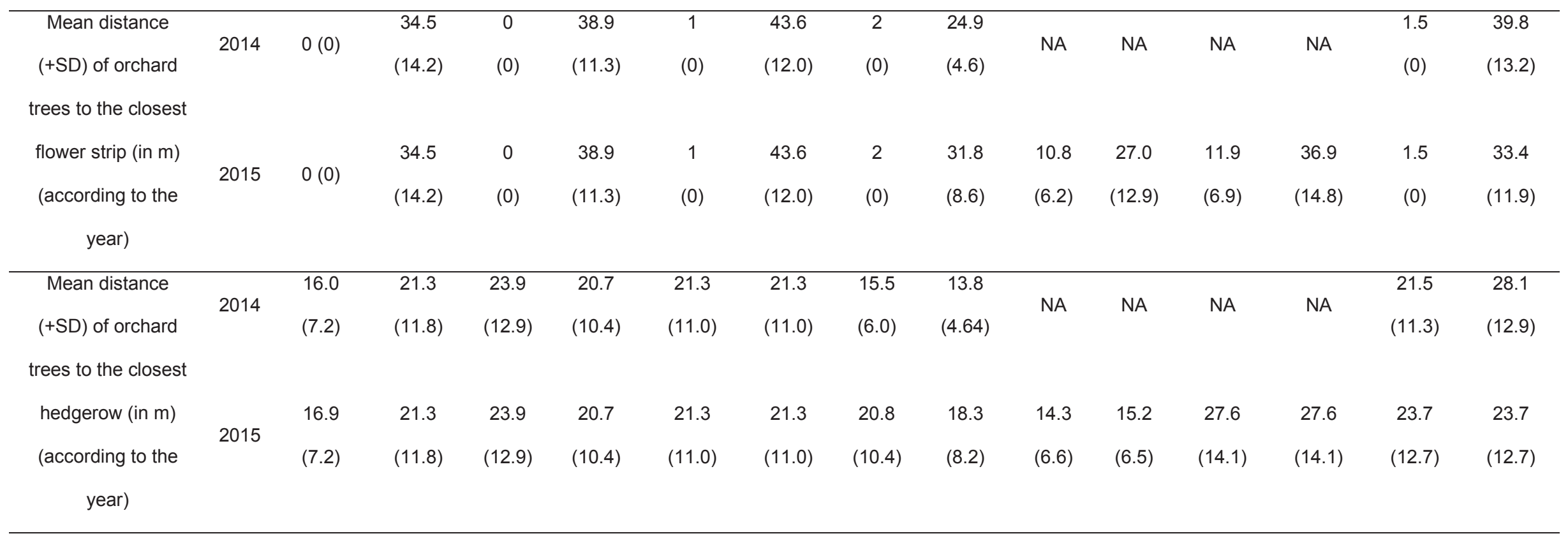


Table 2: Total number of observed arthropods (and range of the mean number for one monitored tree per observation in one studied orchard) by taxonomic group, life stage and year.

\begin{tabular}{|c|c|c|c|c|c|}
\hline & & & \multicolumn{2}{|c|}{ Year } & \multirow[b]{2}{*}{ Total } \\
\hline & & & 2014 & 2015 & \\
\hline \multicolumn{3}{|c|}{ Number of studied orchards } & 10 & 14 & \\
\hline \multicolumn{3}{|c|}{ Total number of observations (date*orchard) } & & & 103 \\
\hline Order & Family & Life stage & & & \\
\hline \multirow[t]{8}{*}{ Diptera } & Syrphidae & & 1083 & 1122 & 2205 \\
\hline & & $5 y$ & (from $5.6^{\wedge}-2$ to 0.50 ) & (from $2.9^{\wedge}-2$ to 1.7 ) & \\
\hline & & & 408 & 429 & 838 \\
\hline & & Larvac & (from $1.0^{\wedge}-2$ to 0.47 ) & (from $3.0^{\wedge}-2$ to 0.51 ) & \\
\hline & & & 9 & 51 & 60 \\
\hline & & 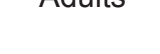 & (from 0 to $1.0^{\wedge}-2$ ) & (from 0 to $5.3^{\wedge}-2$ ) & \\
\hline & & & 1500 & 1602 & 3103 \\
\hline & & All & (from $6.6^{\wedge}-2$ to 0.71 ) & (from $6.0^{\wedge}-2$ to 2.3 ) & \\
\hline \multirow[t]{11}{*}{ Coleoptera } & Coccinellidae & & 533 & 1325 & 1858 \\
\hline & & Eggs & (from 0 to $4.7^{\wedge}-1$ ) & (from 0 to 5.2 ) & \\
\hline & & & 141 & 343 & 484 \\
\hline & & Larvae & (from 0 to $2.7^{\wedge}-1$ ) & (from 0 to $3.8^{\wedge}-1$ ) & \\
\hline & & & 65 & 161 & 226 \\
\hline & & Adults & (from $6.3^{\wedge}-3$ to $8.8^{\wedge}-$ & (from 0 to $3.8^{\wedge}-1$ ) & \\
\hline & & & 2) & & \\
\hline & & & 739 & 1829 & 2568 \\
\hline & & & $\left(6.3^{\wedge}-3\right.$ to 0.79$)$ & (from 0 to 6.4 ) & \\
\hline & Cantharidae & & 17 & 68 & 85 \\
\hline & & Aunits & (from 0 to $1.2^{\wedge}-2$ ) & (from 0 to $4.1^{\wedge}-2$ ) & \\
\hline \multirow[t]{6}{*}{ Hemiptera } & Anthocoridae & & 34 & 92 & 126 \\
\hline & & & (from 0 to $4.5^{\wedge}-2$ ) & (from 0 to $5.0^{\wedge}-2$ ) & \\
\hline & Miridae & & 37 & 114 & 153 \\
\hline & & - & (from 0 to $1.2^{\wedge}-2$ ) & (from 0 to $1.7^{\wedge}-1$ ) & \\
\hline & Nabidae & - & 67 & 0 & 67 \\
\hline & & & (from 0 to $2.4^{\wedge}-1$ ) & (from 0 to 0 ) & \\
\hline
\end{tabular}




\begin{tabular}{|c|c|c|c|c|}
\hline & & \multicolumn{2}{|c|}{ Year } & \multirow[b]{2}{*}{ Total } \\
\hline & & 2014 & 2015 & \\
\hline \multicolumn{2}{|c|}{ Number of studied orchards } & 10 & 14 & \\
\hline \multicolumn{2}{|c|}{ Total number of observations (date*orchard) } & $\begin{array}{c}35 \\
\text { (from } 5 \text { to } 10)\end{array}$ & $\begin{array}{c}57 \\
\text { (from } 5 \text { to } 11 \text { ) }\end{array}$ & 103 \\
\hline \multirow[t]{4}{*}{ Neuroptera } & Chrysopidae & $\begin{array}{c}9 \\
\text { (from } 0 \text { to } 1.2^{\wedge}-2 \text { ) }\end{array}$ & $\begin{array}{c}0 \\
\text { (from } 0 \text { to } 0)\end{array}$ & 9 \\
\hline & Larvae & $\begin{array}{c}0 \\
\text { (from } 0 \text { to } 0)\end{array}$ & $\begin{array}{c}2 \\
\text { (from } 0 \text { to } 6.0^{\wedge}-3 \text { ) }\end{array}$ & 2 \\
\hline & Adults & $\begin{array}{c}0 \\
\text { (from } 0 \text { to } 0 \text { ) }\end{array}$ & $\begin{array}{c}3 \\
\text { (from } 0 \text { to } 2.3^{\wedge}-3 \text { ) }\end{array}$ & 3 \\
\hline & All & $\begin{array}{c}9 \\
\text { (from } 0 \text { to } 1.2^{\wedge}-2 \text { ) }\end{array}$ & $\begin{array}{c}5 \\
\left(\text { from } 0 \text { to } 6.0^{\wedge}-3 \text { ) }\right.\end{array}$ & 14 \\
\hline Dermaptera & Juveniles+adults & $\begin{array}{c}582 \\
\text { (from } 0 \text { to } 0.36)\end{array}$ & $\begin{array}{c}742 \\
\left(\text { from } 2.9^{\wedge}-3 \text { to } 0.60\right)\end{array}$ & 1324 \\
\hline \multirow[t]{3}{*}{ Hymenoptera } & Mummies & $\begin{array}{c}33 \\
\text { (from } 0 \text { to } 3.2^{\wedge}-2 \text { ) }\end{array}$ & $\begin{array}{c}108 \\
\left.\text { (from } 05.4^{\wedge}-2\right)\end{array}$ & 141 \\
\hline & Adults & $\begin{array}{c}12 \\
\text { (from } 0 \text { to } 3.2^{\wedge}-2 \text { ) }\end{array}$ & $\begin{array}{c}25 \\
\text { (from } 0 \text { to } 1.9^{\wedge}-2 \text { ) }\end{array}$ & 37 \\
\hline & All & $\begin{array}{c}45 \\
\text { (from } 0 \text { to } 6.5^{\wedge}-2 \text { ) }\end{array}$ & $\begin{array}{c}133 \\
\text { (from } 0 \text { to } 5.7^{\wedge}-2 \text { ) }\end{array}$ & 178 \\
\hline Araneae & Juveniles+Adults & $\begin{array}{c}296 \\
\text { (from } 0 \text { to } 0.16 \text { ) }\end{array}$ & $\begin{array}{c}440 \\
\text { (from } 0 \text { to } 0.16 \text { ) }\end{array}$ & 737 \\
\hline AlINE & & $\begin{array}{c}3326 \\
\text { (from } 0.10 \text { to } 1.45)\end{array}$ & $\begin{array}{c}5025 \\
\text { (from } 0.30 \text { to } 7.4 \text { ) }\end{array}$ & 8355 \\
\hline Number of RAA & & $\begin{array}{c}206195 \\
\text { (from } 0.77 \text { to } 95.5 \text { ) }\end{array}$ & $\begin{array}{c}554230 \\
\text { (from } 21.0 \text { to } 182.4 \text { ) }\end{array}$ & 760425 \\
\hline $\begin{array}{c}\text { Ratio (natural } \\
\text { enemies per RAA) }\end{array}$ & & $\begin{array}{c}0.016 \\
\left(\text { from } 5.0^{\wedge}-4 \text { to } 0.18\right)\end{array}$ & $\begin{array}{c}0.009 \\
\left(\text { from } 2.4^{\wedge}-3 \text { to } 0.21 \text { ) }\right.\end{array}$ & 0.0109 \\
\hline Ants & & $\begin{array}{c}9279 \\
\text { (from } 2.4^{\wedge}-2 \text { to } 3.8 \text { ) }\end{array}$ & $\begin{array}{c}15578 \\
\text { (from } 4.7^{\wedge}-2 \text { to } 7.1 \text { ) }\end{array}$ & 24857 \\
\hline
\end{tabular}


Table 3: Synthetic overview of the Generalized Linear Mixed models results: “+” (resp. "-") indicates that the factor is favourable (resp. unfavourable) to the considered arthropods. For the distance, a "+" (resp. "-") indicates that the arthropods are more (resp. less) present in the vicinity of the agroecological infrastructure. For the cultivar factor "*" means that cultivar has a significant effect on the response variable $(P A, \log A U C$ or $P D)$ for at least one arthropod stage. 0 indicates that the factor did not significantly influence the variable. NA: not applicable. See Appendix A for detail.

\begin{tabular}{|c|c|c|c|c|c|c|c|}
\hline & RAA & AllNE & Syrphidae & Coccinellidae & Forficulidae & Araneae & Ants \\
\hline \multicolumn{8}{|l|}{ Distance to the } \\
\hline closest & + & 0 & + & - & 0 & 0 & + \\
\hline \multicolumn{8}{|l|}{ hedgerow } \\
\hline \multicolumn{8}{|l|}{ Distance to the } \\
\hline closest flower & - & + & + & + & + & 0 & - \\
\hline \multicolumn{8}{|l|}{ strip } \\
\hline \multicolumn{8}{|l|}{ Cultivar } \\
\hline$(P A / \log A \cup C / P D)$ & $* / * / *$ & $* / * / *$ & $* / 0 / *$ & $* / * / *$ & $* / 0 / 0$ & $* / 0 / 0$ & $* / 0 / 0$ \\
\hline EIQfield use rating & - & - & - & - & - & - & - \\
\hline RAA & NA & + & + & + & + & + & + \\
\hline
\end{tabular}




\section{FIGURE LEGENDS}

Fig. 1. Map of the seven studied locations (two orchards per location). Black dots are the locations studied both in 2014 and 2015. Grey dots are the locations studied in 2015.

Fig. 2. Mean number (+ SE) of RAA (black dot), of all natural enemies (grey dotted line with circle mark), of Syrphidae (all stages) (grey dotted line with triangle mark) and of Coccinellidae (all stages) (grey dotted line with square mark) per monitored apple tree in aphid colonies in 2014 (A) and 2015 (B). 


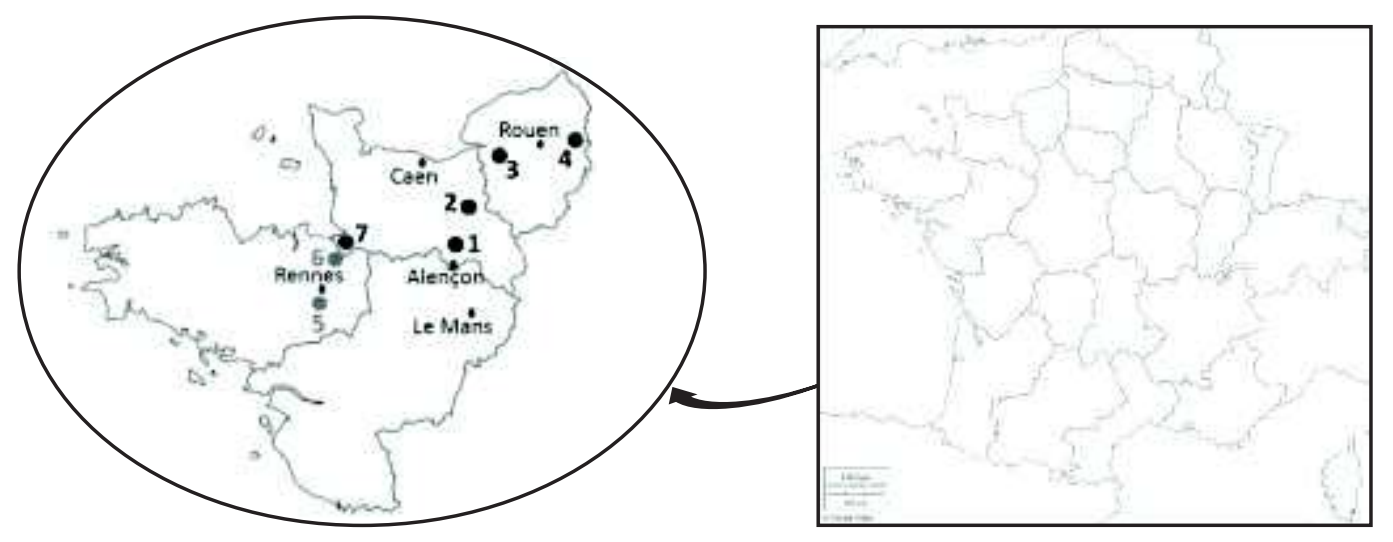

Fig. 1 


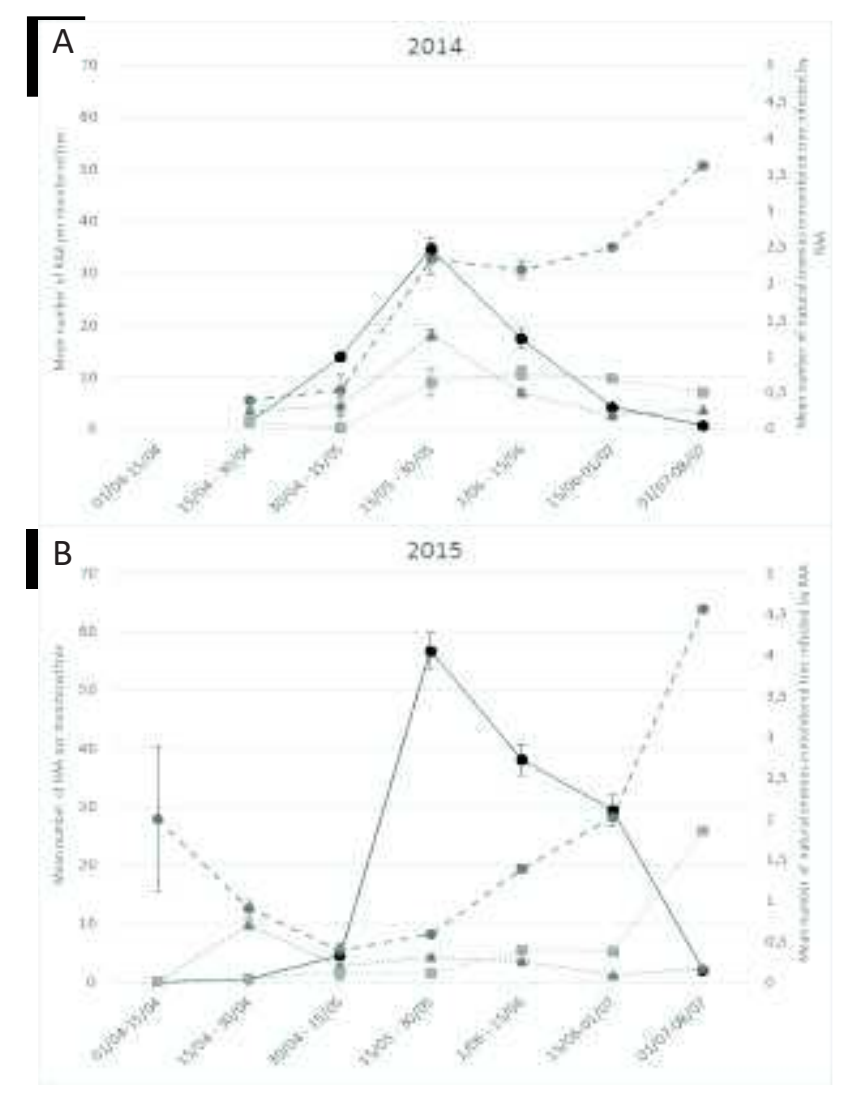

Fig. 2 
Impact of Agroecological Infrastructures on the Dynamics of Dysaphis plantaginea Passerini (Hemiptera: Aphididae) and its Natural Enemies in Apple Orchards in Northwestern France

Laurence ALBERTa, Pierre FRANCKc ${ }^{c}$, Yann GILLES ${ }^{a}$, Manuel PLANTEGENEST ${ }^{\mathrm{b}}$

a Institut Français des Productions Cidricoles, La Rangée Chesnel, 61500 Sées, FRANCE, I albert5@yahoo.fr; yann.gilles@ifpc.eu

b UMR1349 IGEPP, INRA/Agrocampus-Ouest/Université Rennes 1, 65 rue de Saint Brieuc, 35042

$\underline{\text { Rennes Cedex, FRANCE, manuel.plantegenest@agrocampus-ouest.fr }}$

c INRA Plantes \& Systèmes de culture Horticoles, F-84914 AVIGNON Cedex 9, FRANCE, pierre.franck@avignon.inra.fr

\section{Contents}

Appendix A: Results of Generalized Linear Models obtained for each arthropod (by taxon and stage) and each variable.

Appendix B: Sum of arthropods observed per orchard each studied year (2014 and 2015) and mean number of arthropods per sampling date per tree infected with rosy apple aphid 
Appendix A: Results of Generalized Linear Models obtained for each arthropod (by taxon and stage) and each variable. The first line is the pvalue of the variable, when inferior to 0.05 , the second line is the coefficient. NS means no-significant. EIQ means Environmental Impact Quotient. AUC mean Area Under the Curve. DAB means cultivar of Dabinett, DDA means cultivar of Douce de l'Aventcov and JUD means cultivar of Judor.

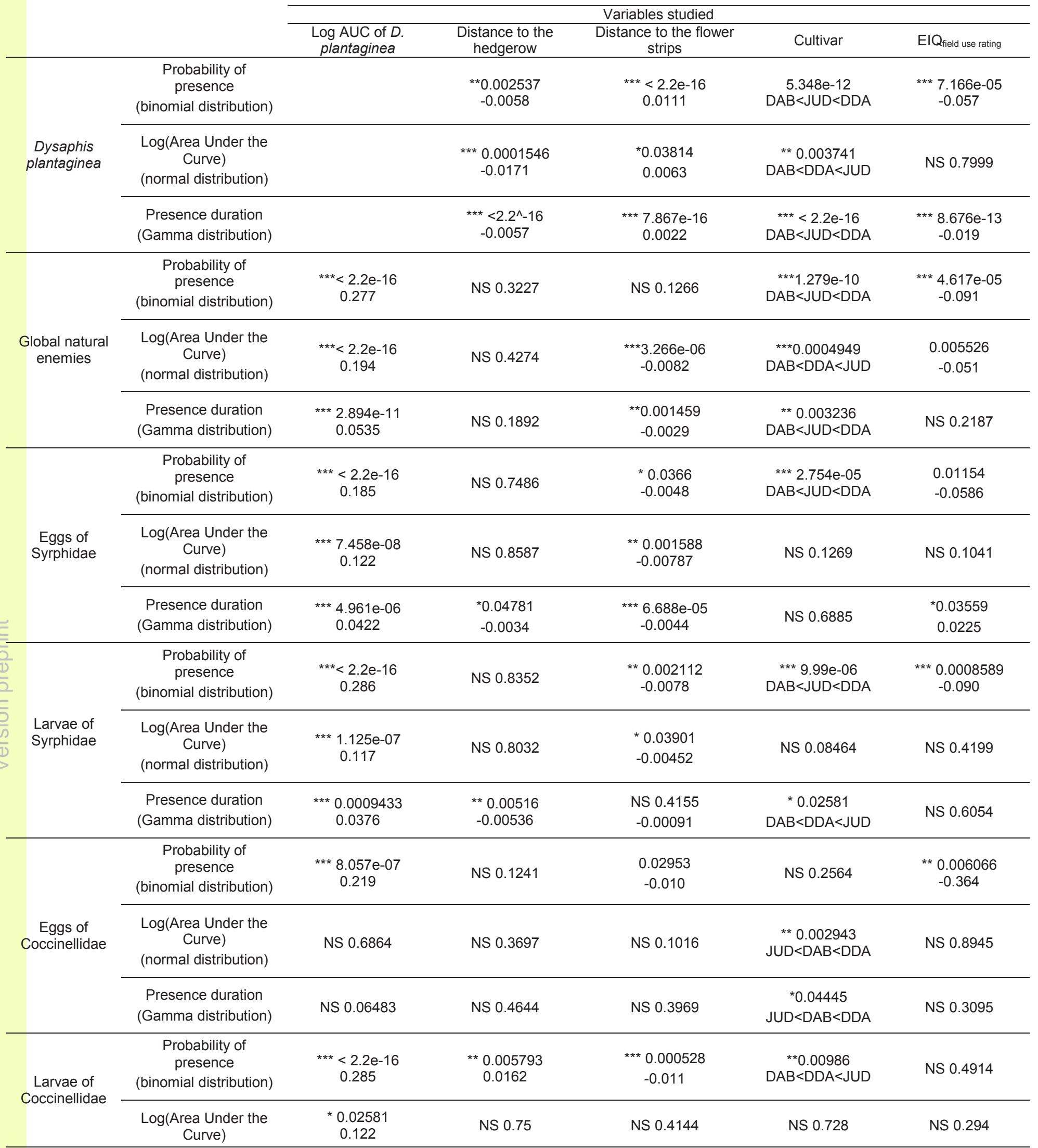




\begin{tabular}{|c|c|c|c|c|c|c|}
\hline & (normal distribution) & & & & & \\
\hline & $\begin{array}{l}\text { Presence duration } \\
\text { (Gamma distribution) }\end{array}$ & NS 0.1201 & $\begin{array}{l}\text { * } 0.03643 \\
0.0057\end{array}$ & NS 0.7773 & $\begin{array}{c}* 0.01121 \\
J U D<D A B<D D A\end{array}$ & NS 0.07431 \\
\hline \multirow{3}{*}{$\begin{array}{l}\text { Adults of } \\
\text { Coccinellidae }\end{array}$} & $\begin{array}{c}\text { Probability of } \\
\text { presence } \\
\text { (binomial distribution) }\end{array}$ & $\begin{array}{l}* * * 437 e-15 \\
0.246\end{array}$ & NS 0.6654 & NS 0.4651 & $\begin{array}{c}\text { * } 0.01922 \\
J U D<D A B<D D A\end{array}$ & NS 0.09964 \\
\hline & $\begin{array}{l}\text { Log(Area Under the } \\
\text { Curve) } \\
\text { (normal distribution) }\end{array}$ & NS 0.491 & NS 0.1347 & NS 0.895 & NS 0.1843 & NS 0.5245 \\
\hline & $\begin{array}{l}\text { Presence duration } \\
\text { (Gamma distribution) }\end{array}$ & NS 0.8494 & NS 0.5724 & NS 0.6548 & $\begin{array}{c}{ }^{*} 0.01378 \\
J U D<D A B<D D A\end{array}$ & NS 0.4131 \\
\hline \multirow{3}{*}{$\begin{array}{l}\text { Forficulidae } \\
\text { (Juveniles and } \\
\text { adults) }\end{array}$} & $\begin{array}{c}\text { Probability of } \\
\text { presence } \\
\text { (binomial distribution) }\end{array}$ & $\begin{array}{c}* * *<2.2 \mathrm{e}-16 \\
0.223\end{array}$ & NS 0.9295 & NS 0.8388 & $\begin{array}{c}{ }^{*} 0.01662 \\
\mathrm{DAB}<\mathrm{DDA}<\mathrm{JUD}\end{array}$ & NS 0.2327 \\
\hline & $\begin{array}{l}\text { Log(Area Under the } \\
\text { Curve) } \\
\text { (normal distribution) }\end{array}$ & $\begin{array}{l}\text { ** } 0.001888 \\
0.0892\end{array}$ & NS 0.1346 & $\begin{array}{l}0.04627 \\
-0.005\end{array}$ & NS 0.05784 & $\begin{array}{c}* * * 0.0006422 \\
-0.097\end{array}$ \\
\hline & $\begin{array}{l}\text { Presence duration } \\
\text { (Gamma distribution) }\end{array}$ & $\begin{array}{c}{ }^{*} 0.03107 \\
0.0304\end{array}$ & NS 0.2126 & $\begin{array}{c}* * 0.005847 \\
-0.00534\end{array}$ & NS 0.5498 & NS 0.9349 \\
\hline \multirow{3}{*}{$\begin{array}{c}\text { Araneae } \\
\text { (Juveniles and } \\
\text { adults) }\end{array}$} & $\begin{array}{c}\text { Probability of } \\
\text { presence } \\
\text { (binomial distribution) }\end{array}$ & $\begin{array}{c}* * * 4.533 e-12 \\
0.146\end{array}$ & NS 0.9254 & NS 0.1275 & $\begin{array}{c}* * * 1.155 e-10 \\
D A B<J U D<D D A\end{array}$ & NS 0.08618 \\
\hline & $\begin{array}{l}\text { Log(Area Under the } \\
\text { Curve) } \\
\text { (normal distribution) }\end{array}$ & NS 0.3479 & NS 0.9367 & NS 0.3193 & NS 0.74 & NS 0.1281 \\
\hline & $\begin{array}{l}\text { Presence duration } \\
\text { (Gamma distribution) }\end{array}$ & NS 0.1252 & NS 0.5216 & NS 0.4528 & NS 0.1029 & $\begin{array}{l}* * 0.001295 \\
-0.059\end{array}$ \\
\hline \multirow{3}{*}{ Ants } & $\begin{array}{c}\text { Probability of } \\
\text { presence } \\
\text { (binomial distribution) }\end{array}$ & $\begin{aligned} * * * & <2.2 \mathrm{e}-16 \\
& 0.405\end{aligned}$ & $\begin{array}{c}* * * 0.000344 \\
-0.0146\end{array}$ & $\begin{array}{c}0.008168 \\
0.0068\end{array}$ & $\begin{array}{c}{ }^{*} 0.01761 \\
J U D<D A B<D D A\end{array}$ & NS 0.8418 \\
\hline & $\begin{array}{l}\text { Log(Area Under the } \\
\text { Curve) } \\
\text { (normal distribution) }\end{array}$ & $\begin{aligned} * * * & <2.2 \mathrm{e}-16 \\
& 0.509\end{aligned}$ & NS 0.5379 & NS 0.8873 & NS 0.4117 & $\begin{array}{l}* \text { * } 0.006257 \\
-0.049\end{array}$ \\
\hline & $\begin{array}{l}\text { Presence duration } \\
\text { (Gamma distribution) }\end{array}$ & $\begin{array}{c}* * *<2.2 \mathrm{e}-16 \\
0.152\end{array}$ & NS 0.1676 & NS 0.8688 & NS 0.6604 & NS 0.2145 \\
\hline
\end{tabular}


Appendix B: Sum of arthropods observed per orchard each studied year (2014 and 2015) and mean number of arthropods per sampling date per tree infected with rosy apple aphid

\begin{tabular}{|c|c|c|c|c|c|c|c|c|c|c|c|c|c|c|c|c|c|c|c|}
\hline \multirow[b]{3}{*}{ Orchard } & \multirow[b]{3}{*}{$\begin{array}{c}\text { Sampling } \\
\text { year }\end{array}$} & \multirow{3}{*}{$\begin{array}{c}\text { Sum of } \\
\text { monitored } \\
\text { tree per } \\
\text { year }\end{array}$} & \multicolumn{4}{|c|}{ Diptera } & \multicolumn{4}{|c|}{ Coleoptera } & \multirow{2}{*}{$\begin{array}{l}\text { Dermaptera } \\
\text { Forficulidae } \\
\end{array}$} & \multicolumn{2}{|c|}{ Hymenoptera } & \multirow{2}{*}{$\begin{array}{c}\text { Araneae } \\
-\end{array}$} & \multirow{2}{*}{$\begin{array}{l}\text { All NE } \\
-\end{array}$} & \multirow{2}{*}{$\begin{array}{c}\text { Ants } \\
-\end{array}$} & \multirow{3}{*}{$\begin{array}{c}\text { Number } \\
\text { of tree } \\
\text { with } \\
\text { RAA }\end{array}$} & \multirow{3}{*}{$\begin{array}{c}\text { Number } \\
\text { of RAA } \\
\text { per tree } \\
\text { infected } \\
\text { by RAA }\end{array}$} & \multirow{3}{*}{$\begin{array}{l}\text { Ratio } \\
\text { NE/RAA }\end{array}$} \\
\hline & & & & & hidae & & & Cocci & ellidae & & & - & & & & & & & \\
\hline & & & Eggs & Larvae & Adults & Total & Eggs & Larvae & Adults & Total & $\begin{array}{l}\text { Nymph } \\
\text { +adults }\end{array}$ & Mummies & adults & $\begin{array}{l}\text { Juvenile } \\
\text { +Adults }\end{array}$ & - & - & & & \\
\hline \multirow{4}{*}{$1 a$} & 2014 & 1980 & 246 & 102 & 0 & 348 & 41 & 5 & 7 & 53 & 337 & 3 & 0 & 105 & 850 & 3580 & 929 & 62291 & \\
\hline & 2014 & 1980 & 0.26 & 0.10 & 0 & 0.37 & 0.04 & $5.3^{\wedge}-3$ & $7.5^{\wedge}-3$ & 0.05 & 0.36 & $3.2^{\wedge}-3$ & 0 & 0.11 & 0.91 & 3.85 & $46,91 \%$ & 67.05 & 0.01 \\
\hline & & & & & & & & & & & & & & & & & & & \\
\hline & 2015 & 2574 & $\begin{array}{l}294 \\
0.43\end{array}$ & $\begin{array}{c}63 \\
0.09\end{array}$ & $\begin{array}{c}3 \\
4.4^{\wedge}-3\end{array}$ & $\begin{array}{l}360 \\
0.53\end{array}$ & $\begin{array}{c}13 \\
0.01\end{array}$ & $\begin{array}{c}1 \\
1.4^{\wedge}-3\end{array}$ & $\begin{array}{c}4 \\
5.8^{\wedge}-3\end{array}$ & $\begin{array}{c}18 \\
0.02\end{array}$ & $\begin{array}{l}411 \\
0.60\end{array}$ & $\begin{array}{l}0 \\
0\end{array}$ & $\begin{array}{l}0 \\
0\end{array}$ & $\begin{array}{c}29 \\
0.04\end{array}$ & $\begin{array}{l}836 \\
1.23\end{array}$ & $\begin{array}{c}3915 \\
577\end{array}$ & $\begin{array}{c}678 \\
26.34 \%\end{array}$ & $\begin{array}{l}123724 \\
18248\end{array}$ & $6.7^{\wedge}-3$ \\
\hline \multirow{5}{*}{$1 \mathrm{~b}$} & & & & & 0 & & 0 & 0 & 5 & & 156 & 0 & & & 425 & & & 20053 & \\
\hline & 2014 & 1980 & 0.29 & 0.01 & 0 & 0.31 & 0 & 0 & $6.3^{\wedge}-3$ & $6.3^{\wedge}-3$ & 0.19 & 0 & 0 & 0.02 & 0.54 & 3.14 & $39,54 \%$ & 38.25 & 0.01 \\
\hline & & & & & & & & & & & & & & & & & & & \\
\hline & 2015 & 2574 & 43 & 21 & $\begin{array}{c}1 \\
14^{\wedge}-3\end{array}$ & 65 & $\begin{array}{l}0 \\
0\end{array}$ & $\begin{array}{c}2 \\
1^{\wedge}-3\end{array}$ & $\begin{array}{c}8 \\
84^{\wedge}-3\end{array}$ & 10 & 211 & $\begin{array}{l}0 \\
0\end{array}$ & $\begin{array}{c}2 \\
2113\end{array}$ & 39 & 382 & 6712 & $\begin{array}{c}943 \\
36 \text { 6. }\end{array}$ & 158824 & $2.4^{\wedge}-3$ \\
\hline & & & & S & $1.4-3$ & & & $2.1-3$ & $8.4-3$ & & 0.22 & 0 & $2.1 *-3$ & 0.04 & 0.40 & 1.11 & $30,03 \%$ & 108.4 & \\
\hline \multirow{4}{*}{$2 a$} & 2014 & 1377 & 282 & 119 & 0 & 401 & 260 & 43 & 9 & 312 & 18 & 1 & 0 & 46 & 821 & 342 & 564 & 16194 & \\
\hline & 2014 & $13 / 1$ & 0.50 & 0.21 & 0 & 0.71 & 0.46 & 0.07 & 0.01 & 0.55 & 0.03 & $1.7^{\wedge}-3$ & 0 & 0.08 & 1.45 & 0.60 & $40,95 \%$ & 28.71 & 0.05 \\
\hline & & & 23 & 36 & 0 & 59 & 53 & 35 & 5 & 93 & 4 & 9 & 0 & 12 & 212 & 12 & 251 & 20977 & \\
\hline & 2015 & 1683 & 0.09 & 0.14 & 0 & 0.23 & 0.21 & 0.13 & 0.01 & 0.37 & 0.01 & 0.03 & 0 & 0.04 & 0.84 & 0.04 & $14,91 \%$ & 83.5 & 0.01 \\
\hline \multirow{4}{*}{$2 b$} & & & 148 & 84 & 0 & 232 & 32 & 15 & 5 & 52 & 8 & 2 & 0 & 81 & 403 & 245 & 743 & 32682 & \\
\hline & 2014 & 1377 & 0.19 & 0.11 & 0 & 0.31 & 0.04 & 0.02 & $6.7^{\wedge}-3$ & 0.06 & 0.01 & $2.6^{\wedge}-3$ & 0 & 0.10 & 0.54 & 0.32 & $53,95 \%$ & 43.98 & 0.01 \\
\hline & & & 13 & 39 & 1 & 53 & 126 & 125 & 7 & 258 & 4 & 5 & 3 & 14 & 382 & 528 & 436 & 57232 & \\
\hline & 2015 & 1683 & 0.02 & 0.15 & $3.9^{\wedge}-3$ & 0.21 & 0.28 & 0.28 & 0.01 & 0.59 & $9.1^{\wedge}-3$ & 0.01 & $6.8^{\wedge}-3$ & 0.03 & 0.87 & 1.21 & $25,90 \%$ & 131.2 & $6.6^{x-3}$ \\
\hline \multirow{4}{*}{$3 a$} & 2014 & 810 & 19 & 3 & 0 & 22 & 15 & 1 & 6 & 22 & 3 & 0 & 0 & 0 & 48 & 20 & 274 & 263 & \\
\hline & 2014 & 810 & 0.06 & 0.01 & 0 & 0.08 & 0.05 & $3.6^{\wedge}-3$ & 0.02 & 0.08 & 0.10 & 0 & 0 & 0 & 0.17 & 0.07 & $33,82 \%$ & 0.95 & 0.18 \\
\hline & & & 235 & 67 & 7 & 309 & 221 & 51 & 37 & 309 & 24 & 0 & 2 & 0 & 691 & 239 & 131 & 22047 & \\
\hline & 2015 & 972 & 1.79 & 0.51 & 0.05 & 2.35 & 1.68 & 0.38 & 0.28 & 2.35 & 0.18 & 0 & 0.01 & 0 & 5.27 & 1.82 & $13,47 \%$ & 168.2 & 0.03 \\
\hline \multirow{4}{*}{$3 b$} & & 810 & 16 & 3 & 0 & 19 & 0 & 0 & 5 & 5 & 5 & 0 & 0 & 2 & 31 & 7 & 285 & 222 & 013 \\
\hline & 2014 & 810 & 0.05 & 0.01 & 0 & 0.06 & 0 & 0 & 0.01 & 0.01 & 0.01 & 0 & 0 & $7.0^{\wedge}-3$ & 0.10 & 0.02 & $35,18 \%$ & 0.77 & 0.13 \\
\hline & & & 21 & 23 & 0 & 44 & 0 & 0 & 4 & 4 & 31 & 0 & 0 & 3 & 89 & 57 & 161 & 8388 & \\
\hline & 2015 & $9 / 2$ & 0.13 & 0.17 & 0 & 0.33 & 0 & 0 & 0.02 & 0.02 & 0.19 & 0 & 0 & 0.01 & 0.55 & 0.35 & $16,56 \%$ & 52.0 & 0.01 \\
\hline
\end{tabular}




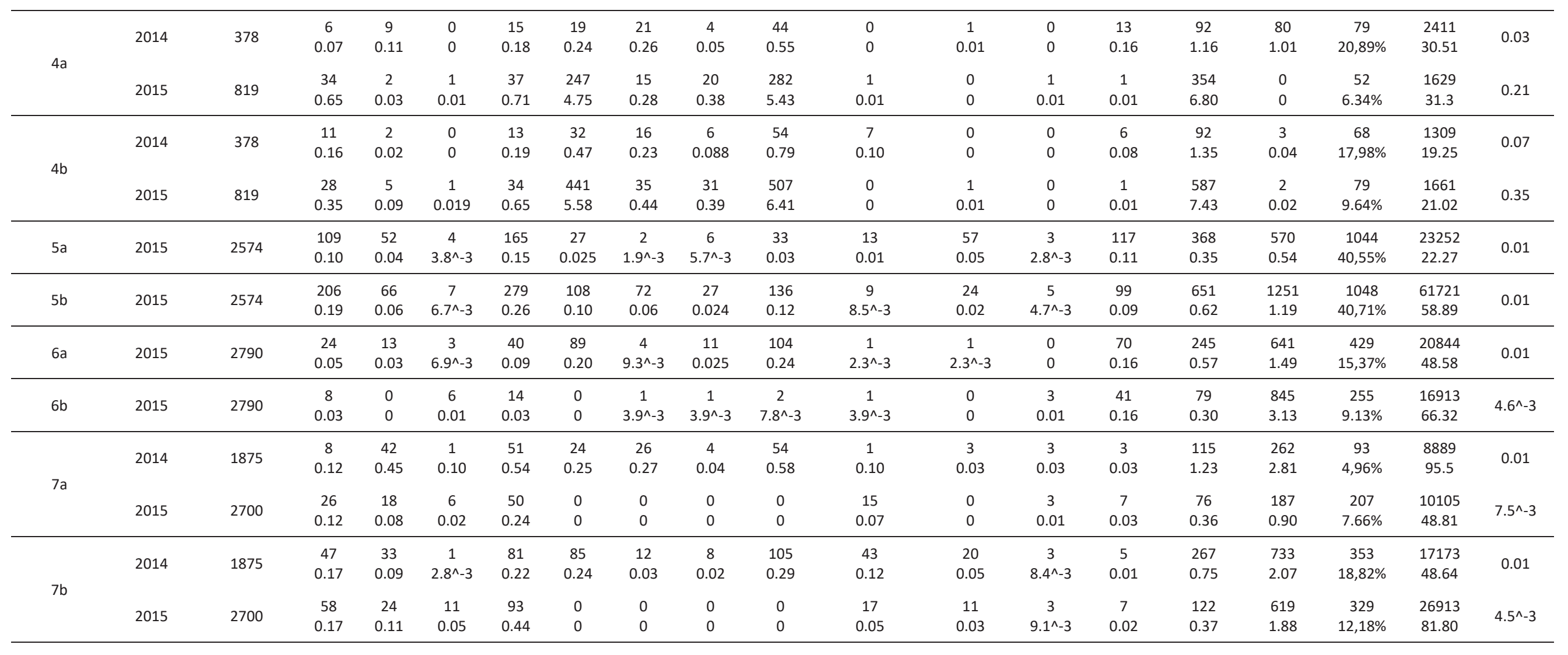

